\title{
Sciendo
}

DOI: $10.1515 /$ sspjce-2020-0014

\section{Review on Alternatives of Aggregates with Alternative Materials in Eastern Africa}

\author{
Cornelius Ngunjiri Ngandu \\ Egerton University \\ Faculty of Engineering, Department of Civil and Environmental Engineering \\ e-mail: ngunjiri55@yahoo.com
}

\begin{abstract}
Normal concrete, with bulky aggregate generally results to large amount of energy and natural resource requirement. Normal aggregates mining and river sand extraction, if done in unsustainably, potentially results in adverse environmental, health or hazardous impacts. There is therefore the need to research and utilize alternative more sustainable construction materials.

This main aim is to review properties of alternative aggregate or mixes with those aggregates within Eastern Africa. In this study, 23 reviews, at optimum aggregate replacement using volcanic materials, crushed rock sand and also fired bone generally indicated good strength performance. Majority of the alternative materials mixes presented indicated higher water absorption, lower slumps/workability and density, compared with the reference. Lower slump could affect compaction, strength or increase costs. Appropriate cost-effective admixtures or plasticizers are recommended while materials exhibiting lower strengths could be explored for non-structural use. Utilization of recycled waste for aggregate could help address resource scarcity and reduce construction environmental footprint.

There should be more research and development of proper procedures and techniques so as to ensure adequate bondage, optimal water/cement ratio and compaction and also use of cost-effective admixtures.
\end{abstract}

Key words: Aggregate, sustainable construction material, review, Eastern Africa

\section{Introduction}

Natural materials such as aggregates, because negative environmental effects that could escalate due to over exploitation and result in massive environmental footprints. Also, normal concrete's ingredients are bulky and the transportation, processing, mixing and placing of resultant material(s) could require a significant amount of energy and costs. According to [1] study on river Kivou, Kenya, sand mining caused river channel morphometric like depth and width, lowering of water table, hence drying up of shallow water, destruction of riparian vegetation and other negative social impacts such as conflict and drug abuse. Research by [2], at Ndarugu, Kenya indicated that quarry activities had some negative impacts such as loss of 
biodiversity that affected the riparian region of River Ndarugu, dust and noise pollution and also some positive impacts such as creation of employment. Therefore, there is a need to research alternative construction materials that achieve the structural requirement as well as addressing the environmental sustainability issue. Under the sustainable development goals 9, target 9.4, part of that included upgrading infrastructure and making it sustainable, with increased resource-use efficiency [3]. According to [4], there is a need for continuous research and development to ensure building materials quality and durability. Engineers and researchers need to research on and the development of proper implementation criteria on alternative construction materials that meet the demand of construction in Eastern Africa region and also reduce the resource environmental footprint.

A major challenge of collection and disposal of waste in East Africa was identified as large amounts of generated waste [5]. Incidentally, some research has been conducted on use of recyclables in construction, with materials such as recycled plastics, glass, construction waste and this could potentially address the challenges of increased waste generation, uncollected waste and demand for construction materials.

\section{Review on Alternative Aggregates}

Tables 1 to 5 are clustered summary based on 23 sources, for alternatives from the Eastern Africa regions, namely:- Kenya, Ethiopia, Uganda, Tanzania \& Rwanda. Abbreviations and terms in the tables include: [C]-Compression; [T]-Tensile/Split Tensile; [F]-Flexural; [SL]Slump/workability; [D]-Density; [WA]:Water absorption material or mixture/water penetration; [E]:Modulus of Elasticity; [DF]:Deflection; [CF]:Compaction Factor; [CT]-Cost; [ML]:Mass loss; [AC]:Air Content; [V]:Void; [S]:Sorption; W:Weight; V:Volume; CA:Coarse Aggregate; FA:Fine Aggregate, the terms 'Lower'/'Higher' are comparisons to control/target/design mix and 'reducing'/'higher' are variation due to increase in alternative.

Scoria, from Ethiopia used by [6] indicated some main sample composition included:$\mathrm{SiO}_{2}(52.53 \%), \mathrm{Al}_{2} \mathrm{O}_{3}(15.49 \%)$ and $\mathrm{Fe}_{2} \mathrm{O}_{3}(11 \%)$ and also fineness modulus of 3.47 , bulk density weight of $1165.7 \mathrm{~kg} / \mathrm{m}^{3}$, water absorption capacity of $0.6 \%$. According to [7], volcanic tuff had specific gravity and water absorption of 2.29 and $16 \%$ respectively and lapilli values for the same properties were 2.53 and $10.2 \%$ respectively. [13] study indicated bulk density, specific gravity and aggregate crushing value of $882 \mathrm{~kg} / \mathrm{m}^{3}, 1.754$ and $47 \%$ and pumice of bulk density and specific gravity of $411 \mathrm{~kg} / \mathrm{m}^{3}$ and 0.886 , sand had bulk density and specific gravity of $1422 \mathrm{~kg} / \mathrm{m}^{3}$ and 2.625 . According to [19], pumice samples had average values of specific gravity, water absorption and dry density of $1.06,32.98 \%$ and $574.6 \mathrm{~kg} / \mathrm{m}^{3}$. According to [18], specific gravity of crushed rock sand was 2.55, sand ranged 2.55-2.63 and water absorption of crushed rock sand averaged $2.4 \%$ and of sand ranged $1.21 \%-1.83 \%$.

Fine aggregates chemical composition from various sources in Kenya, that included natural river sand, rock sand, quarry dust and material of quarry indicated $\mathrm{SiO}_{2}+\mathrm{Al}_{2} \mathrm{O}_{3}+\mathrm{CaO}$ range of $84.3 \%-92.5 \%$, the three components impact on the setting time, early and final strengths and physical properties indicated specific gravities range of $1.73-2.27$, bulk densities between $1327 \mathrm{~kg} / \mathrm{m}^{3}-1684 \mathrm{~kg} / \mathrm{m}^{3}$, water absorption of range $8.3 \%-15.3 \%$ and fineness modulus range of 1.92 - 3.66 [27]. According to [21], crushed ceramic fine aggregates had $16.92 \%$ water absorption compared to $5 \%$ for river sand, hence recommended that crushed ceramic be used 
when saturated surface dry condition to improve concrete workability.

Table 1: Properties of alternative (a) Natural Material:- Inorganics, Rock, Volcanics

\begin{tabular}{|c|c|c|c|c|}
\hline \multirow{2}{*}{$\begin{array}{c}\text { Alternative } \\
\text { Aggregate (Batch) }\end{array}$} & \multicolumn{2}{|c|}{ Strengths (MPa) } & \multirow{2}{*}{$\begin{array}{l}\text { Other Properties } \\
\text { Mix/Agg. \& } \\
\text { (Agg. Replaced) }\end{array}$} & \multirow{2}{*}{ 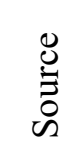 } \\
\hline & $\begin{array}{l}\text { Control/Mix } \\
\text { strength/Design }\end{array}$ & At Optimal replacement & & \\
\hline $\begin{array}{l}\text { Crushed rock } \\
\text { sand-CRS (W) }\end{array}$ & $\begin{array}{l}{[\mathrm{C}]: 22.5 ;[\mathrm{T}]: 1.28 ;} \\
{[\mathrm{F}]: 588.6 ;[\mathrm{E}]: 22}\end{array}$ & $\begin{array}{c}\text { @ } 20 \%:-[\mathrm{C}]: 23.6 ;[\mathrm{T}]: 1.42 ; \\
{[\mathrm{F}]: 686.7 ;[\mathrm{E}]: 23}\end{array}$ & $\begin{array}{l}\text { [WA]: Higher; } \\
\text { [DF]:lower; }(F A)\end{array}$ & {$[18]$} \\
\hline $\begin{array}{c}\text { Volcanic } \\
\text { pyroclastics/tuff- } \\
\text { vt; or lapili-1 (W) }\end{array}$ & {$[\mathrm{C}]: 25.6$} & $\begin{array}{c}\text { @25\%:- [C]:vt:- } 27.8 ; \\
\text { 1:-27.2; }\end{array}$ & $\begin{array}{c}\text { [SL]: Lower(vt); } \\
\text { Higher(l) } \\
\text { [WA]: Higher; }(F A)\end{array}$ & [7] \\
\hline Pumice and scoria & {$[\mathrm{C}]: 17$} & $\begin{array}{c}{[\mathrm{C}]: 24.9 \text { (scoria); } 15.6} \\
\text { (pumice) }\end{array}$ & $\begin{array}{c}\text { [AC]:Higher; [SL]: } \\
\text { Medium workability; } \\
\text { [D]:lower; }(C A)\end{array}$ & {$[13]$} \\
\hline Pumice & Normal Aggregate & & $\begin{array}{l}\text { [D]:Lower; [WA] } \\
\text { higher; }(C A)\end{array}$ & [19] \\
\hline Scoria (W) & {$[\mathrm{C}]: 33.28$} & {$[\mathrm{C}]: 35.3(35 \%)$} & $\begin{array}{l}\text { [SL]: Increasing; [D]: } \\
\text { Lower; }(F A)\end{array}$ & [6] \\
\hline Volcanic Rock & {$[\mathrm{C}]: 25-\mathrm{M} 25$} & {$[C]: 29.6$} & & [20] \\
\hline
\end{tabular}

According to [9] study, the demolished hollow concrete blocks, fine aggregate replacement had fineness modulus, unit weight and absorption capacity of $2.9 \%, 1229.1 \mathrm{~kg} / \mathrm{m}^{3}$ and $6.84 \%$ with river sand fineness modulus, unit weight and absorption capacity reported at $2.78 \%$, $1505 \mathrm{~kg} / \mathrm{m}^{3}$ and $1.73 \%$. Crushed clay bricks had bulk specific gravity of 2.86 and absorption capacity of $14.95 \%$ [29]. According to [12], fine reclaimed asphalt pavement indicated: $\mathrm{SiO}_{2}$ (58.85\%), $\mathrm{CaO}(2 \%)$ and $\mathrm{Al}_{2} \mathrm{O}_{3}(15.6 \%)$. [28] indicated loose bulk density of $1152 \mathrm{~kg} / \mathrm{m}^{3}$ and water absorption of $5.6 \%$ for recycled concrete aggregates. Table 2 shows research on alternative aggregates classified under (b) Building Construction Waste \& Quarry Dust.

Palm kernel shell (PKS) is an organic aggregate, with high pore content hence high water absorption [25]. Research by [26] of PKS from Nsukka urban, Nigeria indicated chemical composition with:- $\mathrm{C}(46.75 \%), \mathrm{H}(5.92 \%), \mathrm{O}(37.97 \%), \mathrm{N}(0.68 \%), \mathrm{S}(<0.08 \%)$ and $\mathrm{Cl}(84 \mathrm{ppm})$ and also composition of structural carbohydrates mainly composed of hemicellulose $(26.16 \%)$ and lignin(53.85\%) and the structural properties could support its application as low cost filler for building or roadworks material. [14] used PKS from Buggala Island-Ugandu, having specific gravity of 1.4 , bulk density of $582.982 \mathrm{~kg} / \mathrm{m}^{3}$ and Aggregate crushing value (ACV) of $2.15 \%$, with Normal Weight Aggregate(NWA) and fine aggregates had specific gravities of $2.58 \& 2.44$ respectively, bulk densities of $1366.23 \mathrm{~kg} / \mathrm{m}^{3}$ and $1665 \mathrm{~kg} / \mathrm{m}^{3}$ respectively and ACV of $17.42 \%$ for NWA. [15] study indicated specific gravities of 1.09 and 1.01 , bulk densities of $553.81 \mathrm{~kg} / \mathrm{m}^{3}$ and $554.51 \mathrm{~kg} / \mathrm{m}^{3}$, water absorptions of $35.64 \%$ and $30.41 \%$, ACV values of $5.37 \%$ and $5.43 \%$, and Aggregate Impact Value (AIV) values of $6.51 \%$ and $6.77 \%$ for untreated and treated PKS respectively. [16] reported the apparent specific gravity, water absorption (24 hours), loose bulk density, ACV and AIV of PKS at 1.44, 34.07\%, $515.28 \mathrm{~kg} / \mathrm{m}^{3}, 2.3 \%$ and $4.74 \%$ respectively and coarse aggregate ACV and AIV values of 
$22.69 \%$ and $15.51 \%$ respectively. Table 3 are alternative aggregates under (c) Agricultural \& Sludge.

Table 2: Properties of alternative (b) Building Construction Waste \& Quarry Dust

\begin{tabular}{|c|c|c|c|c|}
\hline \multirow{2}{*}{$\begin{array}{c}\text { Alternative Aggregate } \\
\text { (Batch) }\end{array}$} & \multicolumn{2}{|c|}{ Strengths (MPa) } & \multirow{2}{*}{$\begin{array}{c}\text { Other Properties } \\
\text { Mix/Agg. \& } \\
\text { (Agg. Replaced) *fresh }\end{array}$} & \multirow{2}{*}{$\begin{array}{l}0 \\
\stackrel{0}{0} \\
\varnothing\end{array}$} \\
\hline & $\begin{array}{c}\text { Control/Mix } \\
\text { strength/Design }\end{array}$ & $\begin{array}{l}\text { At Optimal } \\
\text { replacement }\end{array}$ & & \\
\hline $\begin{array}{l}\text { Crushed ceramic waste } \\
\text { (W) }\end{array}$ & {$[\mathrm{C}]: 24.534[\mathrm{~T}]: 1.9$} & $\begin{array}{c}{[\mathrm{C}]: 21.517} \\
{[\mathrm{~T}]: 1.7}\end{array}$ & $\begin{array}{l}\text { [WA]: Higher; } \\
\text { [SL]:Lower; }(F A)\end{array}$ & [21] \\
\hline Ceramic tile waste & $\begin{array}{c}{[\mathrm{C}]: 22 ;} \\
{[\mathrm{T}]: 2.82 ;[\mathrm{F}]: 5.67}\end{array}$ & $\begin{array}{c}{[\mathrm{C}]: 22.88 \mathrm{MPa}} \\
(5 \%) ;[\mathrm{T}]: 3.18 \\
{[\mathrm{~F}]: 5.97}\end{array}$ & {$[\mathrm{CT}]:$ Lower; $(F A)$} & [22] \\
\hline Ceramic concrete & {$[\mathrm{C}]: 19.03$} & [C]:17.83@50\% & $\begin{array}{l}{[\mathrm{SL}]: \text { Increase then }} \\
\text { Decrease }(F A \& C A)\end{array}$ & [31] \\
\hline $\begin{array}{l}\text { Demolished hollow } \\
\text { concrete block (W) }\end{array}$ & {$[\mathrm{C}]: 37.5$} & {$[\mathrm{C}]: 32.1$} & $\begin{array}{c}{[\mathrm{D}]: \text { Lower; }[\mathrm{SL}]: \text { Reducing; }} \\
(F A)\end{array}$ & [9] \\
\hline Crushed clay bricks(W) & $\begin{array}{c}{[\mathrm{C}]: 17.92 ;[\mathrm{T}]: \approx 1.48} \\
{[\mathrm{~F}]: \approx 2.9}\end{array}$ & $\begin{array}{c}{[\mathrm{C}]: 16.46(@ 20 \%) ;} \\
{[\mathrm{T}]: \approx 1.42(@ 20 \%) ;} \\
{[\mathrm{F}]: \approx 2.58 ;}\end{array}$ & [D]: Lower; $(C A)$ & [8] \\
\hline Recycled Concrete & {$[\mathrm{C}]: \approx 29.5$} & {$[\mathrm{C}]: \approx 28$} & [SL]:Reducing; $(C A)$ & [30] \\
\hline $\begin{array}{l}\text { Reclaimed Asphalt } \\
\text { pavement }(\mathrm{W})\end{array}$ & $\begin{array}{l}{[\mathrm{C}]: 26.72} \\
{[\mathrm{~T}]: 2.13}\end{array}$ & $\begin{array}{l}{[\mathrm{C}]: 20.87(10 \%)} \\
{[\mathrm{T}]: 1.87(10 \%) ;}\end{array}$ & $\begin{array}{c}{[\mathrm{SL}],[\mathrm{CF}],[\mathrm{D}],[\mathrm{V}],[\mathrm{S}]:} \\
\text { Lower; }(F A \& C A)\end{array}$ & [12] \\
\hline Quarry dust & [C]: 30 (Target) & {$[\mathrm{C}]: 27.661$} & & [27] \\
\hline
\end{tabular}

Table 3: Properties of alternative (c) Agricultural \& Sewage Sludge

\begin{tabular}{|c|c|c|c|c|}
\hline \multirow{2}{*}{$\begin{array}{c}\text { Alternative Aggregate } \\
\text { (Batch) }\end{array}$} & \multicolumn{2}{|c|}{ Strengths (MPa) } & \multirow{2}{*}{$\begin{array}{l}\text { Other Properties } \\
\text { Mix/Agg. \& (Agg. } \\
\text { replaced) }\end{array}$} & \multirow{2}{*}{$\begin{array}{l}\ddot{e} \\
\stackrel{0}{0} \\
\dot{0}\end{array}$} \\
\hline & $\begin{array}{c}\text { Control/Mix } \\
\text { strength/Design }\end{array}$ & At Optimal replacement & & \\
\hline Palm Kernel Shell (V) & {$[\mathrm{C}]: 38.6 ;[\mathrm{T}]: \approx 4.8$} & $\begin{array}{c}{[\mathrm{C}]: 25 \%:-33.4 ;} \\
{[\mathrm{T}]: \approx 4}\end{array}$ & $\begin{array}{c}\text { [SL], [D]:Lower; } \\
\text { [WA]:Higher; }(C A)\end{array}$ & [14] \\
\hline $\begin{array}{l}\text { Palm Kernel Shell- } \\
\text { Lime treated }\end{array}$ & $\begin{array}{l}\text { [C]: } 30.44 ; \\
{[\mathrm{T}]: 3}\end{array}$ & $\begin{array}{l}\text { [C]: 27.03; } \\
{[\mathrm{T}]: 2.51}\end{array}$ & $\begin{array}{l}\text { [SL], [D]: Lo } \\
\text { [WA]: Higher; }\end{array}$ & {$[15]$} \\
\hline Kernel shell & $\begin{array}{c}{[\mathrm{C}]: 31.3 ;} \\
{[\mathrm{T}]: 2.1 ;[\mathrm{F}]: 4.25}\end{array}$ & $\begin{array}{c}{[\mathrm{C}]: 26.5(25 \%)} \\
{[\mathrm{T}]: 1.8(25 \%) ;[\mathrm{F}]: 3.139}\end{array}$ & $(C A)$ & [16] \\
\hline Sewage sludge & $\begin{array}{c}{[\mathrm{C}](\mathrm{RT}): 38.04 ;} \\
{[\mathrm{C}](\mathrm{ET}): 7.08}\end{array}$ & $\begin{array}{c}{[\mathrm{C}](\mathrm{RT}): 39.29(5 \%)} \\
{[\mathrm{C}](\mathrm{ET}): 8.51(5 \%) ;}\end{array}$ & $\begin{array}{l}\text { 5\% ML (@ET, } 8 \\
\text { hours): Lower }(F A)\end{array}$ & [23] \\
\hline
\end{tabular}

RT:Room Temperature; ET:Elevated Temperature;

Research by [28] had control concrete with volcanic scoria coarse aggregates, composed mainly of $\mathrm{SiO}_{2}(72.755 \%), \mathrm{Al}_{2} \mathrm{O}_{3}(13.482 \%), \mathrm{CaO}(1.09 \%), \mathrm{Fe}(6.082 \%)$, and also partial 
replacement (5\% to $15 \%$ weight replacement) of the scoria, using pre-coated waste plastic, from plastic papers and/or bags, by hot process. The water absorption varied with pre-coated waste plastics, from $13.06 \%$ with $0 \%$ pre-coating to $5.97 \%$ with $15 \%$ pre-coating [28]. [31] used coarse and fine rubber tyre aggregate with dry rodden densities indicated at $706 \mathrm{~kg} / \mathrm{m}^{3}$ and $674 \mathrm{~kg} / \mathrm{m}^{3}$ respectively, and crushing value of coarse rubber tyre aggregate at $0.02 \%$. Table 4 shows research on alternative aggregates classified under (d) Polymers and Rubber.

Table 4: Properties of alternative (d) Polymers and Rubber

\begin{tabular}{|c|c|c|c|c|}
\hline \multirow{2}{*}{$\begin{array}{c}\text { Alternative } \\
\text { Aggregate (Batch) }\end{array}$} & \multicolumn{2}{|c|}{ Strengths (MPa) } & \multirow{2}{*}{$\begin{array}{l}\text { Other Properties } \\
\text { Mix/Agg. \& (Agg. } \\
\text { replaced) }\end{array}$} & \multirow{2}{*}{$\begin{array}{l}\dot{0} \\
\stackrel{\Xi}{0} \\
\dot{0}\end{array}$} \\
\hline & $\begin{array}{l}\text { Control/Mix } \\
\text { strength/Design }\end{array}$ & At Optimal replacement & & \\
\hline Waste rubber tires & $\begin{array}{l}{[\mathrm{C}]: 40.91(\mathrm{C} 25) ;} \\
{[\mathrm{C}]: 49.26(\mathrm{C} 30)}\end{array}$ & $\begin{array}{c}\text { @10\%:- [C]:35.6-C25; } \\
{[\mathrm{C}]: 42.38-\mathrm{C} 30}\end{array}$ & $\begin{array}{c}\text { [SL]: Higher; } \\
\text { [D]:Lower; }(C A)\end{array}$ & [11] \\
\hline \multirow{3}{*}{ Waste rubber tyres } & {$[\mathrm{C}]: 19.03$} & [C]:4.15 (@50\%) & {$[\mathrm{D}],[\mathrm{SL}]:$ Lower $(F A)$} & \multirow{3}{*}[17]{} \\
\hline & {$[\mathrm{C}]: 19.03$} & {$[\mathrm{C}]: 4.1(@ 50 \%)$} & {$[\mathrm{D}],[\mathrm{SL}]:$ Lower $(C A)$} & \\
\hline & $\begin{array}{c}{[\mathrm{C}]: 19.03} \\
{[\mathrm{~F}]: 3.5[\mathrm{~T}]: 2.61}\end{array}$ & $\begin{array}{c}{[\mathrm{C}]: 2.489} \\
(25 \%) ;[\mathrm{F}]: 1.22 ;[\mathrm{T}]: 1.4\end{array}$ & $\begin{array}{c}{[\mathrm{D}],[\mathrm{SL}]: \text { Lower }(F A \&} \\
C A)\end{array}$ & \\
\hline $\begin{array}{l}\text { Plastic pre-coated to } \\
\text { scoria }(\mathrm{W})\end{array}$ & $\begin{array}{c}{[\mathrm{C}]: 32.505 ;} \\
{[\mathrm{F}]: 3.21 ;[\mathrm{T}]: 2.74}\end{array}$ & $\begin{array}{c}\text { @ } 5 \% \text { pre-coat, } \\
{[\mathrm{C}]: 35.905 ;} \\
{[\mathrm{F}]: 3.32 ;[\mathrm{T}]: 2.79}\end{array}$ & $\begin{array}{c}{[\mathrm{SL}],[\mathrm{D}]: \text { Deceasing; }} \\
(C A)\end{array}$ & [28] \\
\hline
\end{tabular}

Study by [24] indicated that bone aggregates had ACV of $29 \%$, an indication of suitability of bones as aggregates in concrete, bulk density of crushed bones of $9.18 \mathrm{Kn} / \mathrm{m}^{3}$ and $19.5 \%$ water absorption for fired bones, higher than of normal aggregates. Table 5 shows research on alternative aggregates classified under (e) others: sawdust and bones.

Table 5: Properties of alternative (e) other- sawdust and bones

\begin{tabular}{|c|c|c|c|c|}
\hline \multirow{2}{*}{$\begin{array}{c}\text { Alternative } \\
\text { Aggregate (Batch) }\end{array}$} & \multicolumn{2}{|c|}{ Strengths (MPa) } & \multirow{2}{*}{$\begin{array}{l}\text { Other Properties } \\
\text { Mix/Agg. \& (Agg. } \\
\text { replaced) }\end{array}$} & \multirow{2}{*}{$\begin{array}{l}\ddot{D} \\
\stackrel{\Xi}{0} \\
\ddot{D}\end{array}$} \\
\hline & $\begin{array}{c}\text { Control/Mix } \\
\text { strength/Design }\end{array}$ & $\begin{array}{l}\text { At Optimal } \\
\text { replacement }\end{array}$ & & \\
\hline \multirow{2}{*}{$\begin{array}{l}\text { Sawdust, using } \\
\text { OPC \& PPC } \\
\text { cements (V) }\end{array}$} & {$[\mathrm{C}]: 22.2-\mathrm{OPC}$} & {$[\mathrm{C}]: 21.4(5 \%)$} & \multirow{2}{*}{$\begin{array}{c}\text { [SL]:Decreasing }>5 \% \\
\text { [D]:Decreasing; } \\
\text { [WA]:Increasing; } \\
\text { [CT]:Lower-PPC; }(F A)\end{array}$} & \multirow[b]{2}{*}[10]{} \\
\hline & {$[\mathrm{C}]: 23.2-\mathrm{PPC}$} & {$[\mathrm{C}]: 21.8(5 \%)$} & & \\
\hline Fired bones & {$[\mathrm{C}]: 21.25$} & [C]: $32.83(@ 50 \%)$ & {$[\mathrm{D}]:$ Lower $(F A \& C A)$} & [24] \\
\hline
\end{tabular}

\subsection{Density/ Weight and Lightweight}

Based on Tables 1 to 5, all the 13 sources where densities- fresh, aggregate or hardened- were tabulated, indicated that the densities were lower than those of control samples or natural aggregates. This applies to across the board, (a) to (e).

Reduced density -scoria as fine aggregate partial replacement in concrete- could help reduce 
self-weight for designing hence reduces sections and attain savings [6]. Lower specific gravity of tuff/lapili replacement as fine aggregate are capability of light weight concrete [7]. Reduced density could mean reduced overall weight of building, hence savings on structural elements [8]. Density reduction, with increasing proportion of sawdust as fine aggregate was attributed to lesser density of sawdust [10]. Reducing weight as rubber percentage, increase, for Partial replacement of coarse aggregate in concrete study was attributed to lower specific gravity of rubber [11], also the same reason was possible the cause for reduced density with partial replacement of reclaimed asphalt pavement (RAP) coarse and fine aggregates [12].

Lower density, using of pumice or scoria as coarse aggregate was possible due to insufficient compaction or variation in empirical mix design formulae [13]. Lower weight of mixes with Palm Kernel Shell (PKS) partial replacement of coarse aggregate was possibly due to lower specific gravity of PKS [14, 15], lower compaction [14] and lead to porous concrete [14]. Based on [16] study, partial replacement of coarse aggregate with kernel shell and use of steel tyre, beam with $25 \% \& 50 \%$ and optimal fiber content qualified as structural lightweight concrete.

Study by [17] on partial or full replacement of aggregate with waste tyre indicated that density decrease due to lighter weight rubber tyres.

\subsection{Cost}

Comparative costs of mixes with saw dust replacement for fine aggregate according to [10] were lower. Study of partial replacement of ceramic tile waste by [22] also indicated lower cost. Higher demand for cement, by use of pumice or scoria as coarse aggregate could be offset by transportation cost of normal aggregate [13]. According to [22] use of ceramic waste as replacement for fine was cheaper than natural sand. Properties suitable for aggregate replacement, usage could save cost as an alternative construction material [6]. Partial replacement of sand with sawdust indicated lower cost with partial replacement [10].

\subsection{Fresh Concrete}

Overall, based on tabulation in tables $1-5$, mainly indicated that slumps/workability were lower compared to the control/standard/design or reducing as alternative material content increased. Slump or workability indicators, based on extracted data tabulated in tables 1,2,3 \& 4 indicated that with increasing proportion of alternative aggregate: -In group (a.) [7] indicate lower/decreasing slump- fine alternative aggregate replacement using volcano tuff- and higher for lapili and [6] indicate higher/increasing slump (fine alternative aggregate replacement using scoria) and [13] indicated medium workability- coarse alternative aggregate replacement using scoria/pumice; -In group (b) 4 sources indicated lower/reducing slumps, 2 for alternative fine aggregates replacement, 1 for alternative coarse aggregates replacement and 1 for fine \& coarse aggregate alternative. [31] indicated increasing then decreasing slump with ceramic concrete coarse and fine aggregate increase; -In group (c) 2 sources indicated lower slumps, 2 for alternative coarse aggregates replacement; -In group (d) 2 sources indicated lower/decreasing slumps and 1 higher;

According to [19] grading of aggregate has an effect on workability and suitability of concrete mix, and sieve analysis test on pumice coarse aggregate showed that they compared well with normal crushed aggregates. Decreasing workability, of tuff/lapili replacement as fine

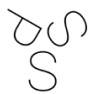


aggregate was possibly due to insufficient water to lubricate the increased surface areas [7]. Slump and workability, for replacement of fine aggregate in concrete with crushed ceramic waste was affected by water absorption of aggregate [21]. Low values $(\leq 25 \mathrm{~mm})$ slump was attributed to high absorption capacity of recycled fine aggregate, due to fine materials resulting from the old mortar, for the demolished hollow concrete block as (partial) replacement [9]. According to [12] study using reclaimed asphalt pavement (RAP) as coarse and fine aggregate partial replacement, decrease slump could be due to absorption of water by fine dust around the RAP and water could have been controlled by RAP particles, and possibly not able to move freely. Study on PKS as partial replacement of coarse aggregate, workability reduction, with increase in PKS amount was possibly due to absorptive value or use of finer PKS $[14,15]$ and reduced workability could have resulted to lower compaction and superplasticizers (SP's) usage to improve workability was recommended [14].

Slump loss increase, with increase in proportion of sawdust as fine aggregate indicated increasing sawdust retard hydration cement reaction, possibility due to lignin in sawdust [10].

\subsection{Water Absorption/penetration, Sorption \& Silt Content/Fineness}

A majority of the sources as tabulated in table 1,2,3 \& 5 relating to absorption/sorption, showed higher or increasing results compared to the control/standard/design.

Higher water absorption of crushed rock sand (CRS) as fine aggregate replacement, could be due to high fineness of CRS [18]. [14] study on PKS partial replacement of coarse aggregate, high water absorption could have been due to convex surface micro-tiny pores. According to [10] study on partial replacement of sand by sawdust as fine aggregate, larger surface area need more water and increasing water permeability could have been due to porous nature of sawdust, with increasing sawdust amount. High sorption of reclaimed asphalt pavement (RAP) as coarse and fine aggregate partial replacement may have been be due to melted asphalt layer for RAP aggregate and also lower absorption by RAP aggregate [12].

[22] study on ceramic tile waste replacement of fine aggregate, recommended careful selection of w/c ratio, to avoid long curing period that would increase water absorption due to clay in ceramic tiles. [9] study on demolished hollow concrete block as (partial) replacement of fine aggregate indicated significantly higher silt content compared with the desired.

\subsection{Strengths, Failure and Deformation Modes}

Generally most studies for (a) Inorganics, Rock, and Volcanic Materials indicated higher optimum strengths, for maximum strengths, after replacement with alternative aggregate; however, most studies in Building Construction Waste \& Quarry Dust, Agricultural \& Sewage Sludge and Sawdust indicated lower strength after replacement of aggregates.

Comparison between highest/optimum strengths achieved by replacement material and control/design/standard as tabulated in tables 1 to 5, indicated:- In cluster (a) [13] indicated higher optimum/highest strength for scoria and lower for pumice, after replacement compared to the control/design and 4 sources in this group indicated higher optimum/highest strength after replacement, hence majority of the maximum strength after replacement indicated higher strength; In cluster (b) 7 sources indicated lower strengths, for optimum/maximum strength after replacement with alternative materials, with [22] indicated higher strength; In cluster (c) 3 sources indicated lower strengths, after (partial) replacement of coarse aggregate 
and [23] indicated higher maximum strength after optimal partial replacement, of fine aggregate; In cluster (d) 2 sources indicated lower strength and [28] indicated source higher strength; in (e) [24], indicated higher strength, for the highest strength after replacement and [10] indicated lower strength.

Increased strength at -partial replacement of Scoria as fine aggregate- with increase scoria (at least to some \%) was attributed to inherent physical properties (less silt and clay), almost similar water absorption, less silt could have aided in better hydration and better bondage, blending with scoria enabled well-graded size distribution, increase solid volume hence better strength and formation of paste/aggregate interaction decrease due to less filler or packing effect [6]. Some additive or admixtures could improve light weight concrete strength [13].

Tensile for concrete - though low assist in crack prevention [21]. [8] study on replacement of coarse aggregate with crushed clay bricks indicated that strengths were affected by:- lower specific gravity of bricks; Strength (compressive) reduction was attributed to mortar at bricks surface cracks in aggregate itself (could happen during crushing) other factors could be density, size interlocking and aggregate rigidity; Poor bonding between paste and brick could have possibly caused lower tensile strength. Lower workability with increasing PKS as coarse aggregate and lower compaction possibly cause strength reduction [14]. According to [15], reduced tensile strength with partial replacement of PKS as coarse aggregate may have been due to poor compaction and increased surface area of lime treated PKS.

Reducing strength with increase rubber proportion may have been due to reduced solid carrying material quantity and insufficient adhesion at the rubber aggregate surface [11] modified. Study by [17] on partial or full replacement of aggregate with waste tyre indicated:at failure generally specimen remain intact; increased cohesiveness with increased rubber tyres, hence could sustain deformation with less compression.

According to [24], study on bone as replacement (partial or full) for fine or/and coarse aggregate, specimen with higher bone content did not disintegrate compared to those with those that had less or no bone content. A possible reason for lower strength for sand replaced samples, with sawdust is the low compression strength of sawdust, since to some extend, the aggregate strength contribute to that strength of concrete [10].

\subsection{Economic, Environmental, Energy, Information \& Other Considerations}

Aggregate extraction process is not environmentally friendly [22]. Tuff/lapili material as (partial) replacement of aggregate in concrete could be used to replace sand \& reduce environmental degradation [7]. Diversification of aggregate material could reduce environmental degradation [21]. Solution on the dual challenge-of increasing waste and natural aggregate scarcity and cost- maybe eased by environmental protection [22]. According to [8] usage of waste clay in aggregate-coarse- can address issue of environmental threat of due to waste clay and conservation of natural materials.

Scoria is widely available in Ethiopia, usage could save energy as an alternative construction material [6]. [19] recommended that pumice could be used as light weight aggregate for domestic houses, with light loading and high strength not required and the aggregate availability in Kenya could potentially be produced commercially for low lightweight concrete. [9] study on recycling demolished hollow concrete block as (partial) replacement of fine aggregate could aid in reduction of environmental pollution, and promote construction sustainability and conservation of non-recyclable natural resources. [10] on partial

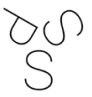


replacement of sand with sawdust, could aid in addressing the non-availability of sand in Tepi, Ethiopia.

Based on [8] study, $18.72 \%$ replacement of coarse aggregate with crushed clay bricks as coarse aggregate was recommended for use in non-load bearing members e.g. walls, facades or architectural units. Study by [17] on partial or full replacement of aggregate with waste tyre indicated that it could produce material that can sustain deformation with less compression hence suitable for footpath and/or architectural finishes, if they have light unit weight. [14], recommended the use of PKS as partial replacement of coarse aggregate, for structural lowcost (cost-effective) application, potentially reducing normal weight aggregate demand hence mining and reduce environmental pollution.

Figure 1 shows the comparison for strengths, slumps/workability and water absorption based on reviews in tables 1 to 5, groups (a) showing studies with highest optimum strengths.

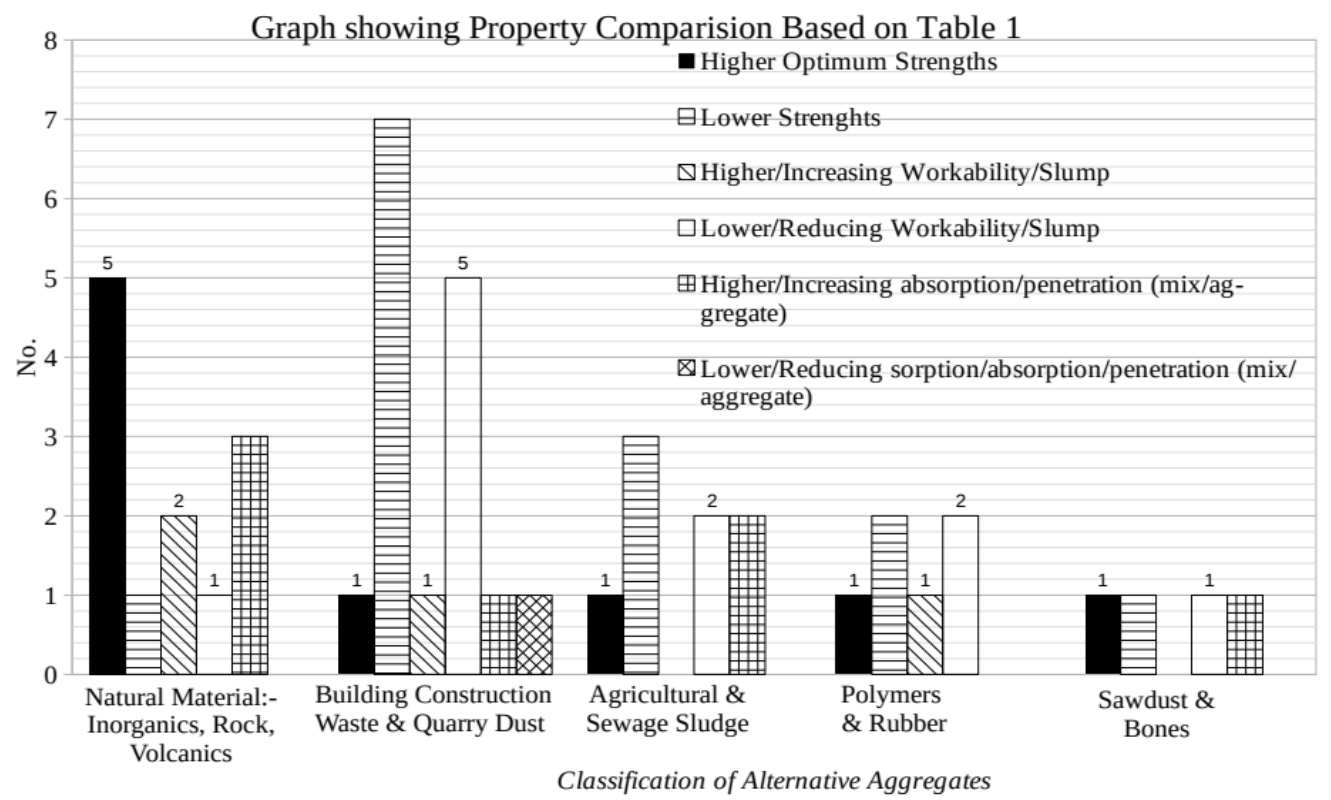

Figure 1: Property comparisons based on various clusters of aggregate types

\section{Conclusion and Recommendation}

Based on this review, strength performance for partial or full replacement, at optimum replacement, by use of Natural Material:- Inorganics, Rock such as scoria or rock volcano materials, had higher strengths (at optimum/maximum strength after replacement), also the same for [24] study for partial replacement of aggregate using fire bones. Hence, materials such as volcanic materials, crushed rock sand and also fired bone should be considered for aggregate replacement for structural sections concrete, at optimum replacement. However, the water absorption and density were generally lower or decreasing compared with the reference. Based on this, materials, such as rock and scoria at optimum replacement could be feasible for structural use, but adequate mix designs and standards should be developed to address issues such as water/binder ratio requirement and workability.

For (b) building construction waste \& quarry dust, (c) agricultural \& sewage sludge, (d) polymers and rubber and also sawdust in (e), mainly indicated generally lower or reducing

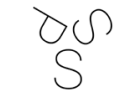


slumps with increase in alternative aggregate compared to reference value. Lower slumps/ workability could eventually affect compaction and strength. To address this, appropriate admixtures or plasticizers should be applied. Most strengths in clusters (b) to (d) were lower compared to the reference. Sustainable and large scale recycling of this materials, for structural or non-structural concrete or mortar could not only address resource scarcity but also may result to environmental benefit.

The two cost evaluation indicated that use of alternative materials for fine aggregates could result to lower cost for significantly large application. The use of alternative aggregates replacement could result to cost savings. However, with majority of studies indicating higher or increasing water absorption material, mixture, alternative aggregates or mixture/water penetration, compared to the control/standard/design, this could mean additional cost such as water, need for admixtures or need for more compaction effort or equipment.

There should be more research and development of proper procedures and techniques to ensure that particle bondage are strong, optimal water/cement ratio are achieve and compaction optimized. Further studies are required for modulus of elasticity of concrete having fired bones and the effect of fire [24] and the same for concrete or blocks where there is partial replacement of aggregates with alternative materials, having adequate strengths. There should be research and development towards a cost-effective, ready available admixture, additives and plasticizers that could be applied to improve alternative coarse and fine aggregates materials application in concrete or block making.

\section{Acknowledgment}

I acknowledge authors and publishers that have made it possible for accessibility of research used.

\section{References}

[1] Gathogo, \& Amino (2017). Social-Environmental Effects of River Sand Mining: Case of Ephemeral River Kivou in Kitui County, Kenya. IOSR Journal of Humanities and Social Science. 22 (11), 31-37. DOI: 10.9790/0837-2211103137

[2] Waweru, S.W., Njoroge, J.B. \& Adimo, A.O. (2018). Management Status and Perception of Post-Quarried Site in Ndarugu Kiambu, Kenya. Africa Journal of Environmental Science and Technology. 12 (8), 268-282. DOI: 10.5897/AJEST2018.2474

[3] United Nation Department of Economic and Social Affairs: Sustainable Development. Building Resilient Infrastructure Promote Inclusive and Sustainable Industrialization and Foster Innovation. Retrieved: 2020 https://sdgs.un.org/goals/goal9.

[4] Kitio (2017). Innovative Building Materials for Sustainable Construction in Africa. Topical Session Innovative Building Materials Global science \& Technology Innovation Conferences. 2017: $23^{\text {rd }}-26^{\text {th }}$ October, 2017.

[5] Aryampa, S. Maheshwari, B. Sabiili, E. Bateaanya, N.L. \& Bukenya B. (2019). Status of Waste Management in East African Cities: Understand the Drivers of waste Generation, Collection and Disposal and Their Impacts on Kampala City's Sustainability. Sustainability. 11, 5523: DOI:10.3390/su11195523

[6] Getachew, K.W., Muge, M.D., Fekadu, F.F. \& Tewodros, G. (2019). Suitability of Scoria as Fine Aggregate and its Effect in Properties of Concrete .Suitability, 11, 4647. DOI: 10$3390 / 5411174647$

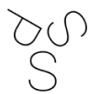


[7] Okwadha, G.D.O. \& Ngengi, K.J. (2016). Partial Replacement of River Sand with Volcanic Pyroclastics as Fine Aggregates in Concrete Production. IOSR-Journal of Mechanical and Civil Engineering. 13 (5), 41-45. DOI: 10.9790/1684-1305034145

[8] Odera, B.J., Mutuku, R.N. \& Kabubo, C.K. (2015). Mechanical Characteristics of Normal Concrete Partially Replaced with Crushed Clay Bricks. International Journal of Civil Engineering and Technology (IJCIET). $62-75$. http://www.iaeme.com/citearticle.asp?Ed=4478\&Jtype=IJCIET\&VType=6\&Itype=1

[9] Nigussie, L.F., Muge, M.M. \& Ghebrab, T. (2019). Recycled Fine Aggregate from Demolished Hollow Concrete Block for Green Concrete in Ethiopia. Global Journal of Engineering Science. 3 (2): 2019. GJES.MS.ID.000559. DOI: 10.33552/GJES.2019.03.000559

[10] Lemma. Study of Partial Replacement of Sand with Wanza Sawdust to Produce Concrete. Msc. Thesis. Addis Ababa University, 2019. http://213.55.95.56/bitstream/handle/123456789/19551/Getish\%20Lemma.pdf?sequence=1\&is Allowed $=\mathrm{y}$

[11] Gemeda \& Alemu (2020). Water Rubber Tires: A Partial Replacement of Coarse Aggregate in Concrete Floor Tile Production. American Journal of Civil Engineering. 8 (3), 57-63. DOI: 10.11648/j.ajce.20200803.12

[12] Getahun, M.A., Shitote, S.M. and Gariy, Z.C.A. (2018). Experimental Investigation of Engineering Properties of Concrete Incorporating Reclaimed Asphalt Pavement and Rice Husk Ash. Buildings, 8:15 DOI:10.3390/buildings8090115

[13] Mrema \& Mboya. Feasibility of LightWeight Aggregate Concrete for Structural \& Nonstructural Works in Tanzania [Electronic Version]. University of Dar es Salaam Research Repository- 2013.

[14] Philips, E.S., Mutuku, R.N. \& Mwero, J.N. (2017). Palm Kernel Shell as Partial Replacement of Normal Weight Aggregate in Concrete. Civil \& Environmental Research (CER). 9 (11). https://iiste.org/Journals/index.php/CER/article/download/39565/40686

[15] Djima, M.O.A., Mang'uriu, G.N. \& Mwero, J.N. (2018). Experimental Investigation of Lime Treated Palm Kernel Shell and Sugercane Bagasse Ash as Partial Replacement of Coarse Aggregate and Cement Respectively in Concrete. Open Journal of Civil Engineering, 8, 358372. DOI:10.4236/ojce.2018.84027

[16] Dorr, B.J., Kanali C.L., \& Onchiri R.O. (2019). Effects of Recycled Tyre Steel Fibres on the Compressive, Splitting Tensile and Flexural Strenghts of Structural Lightweight Concrete Using Palm Kernel Shells as Partial Replacement of Coarse Aggregates [Electronic Version]. Civil and Environmental Research (CER), 11 (6). PP 35-41. July, 2020. Institutional repository, Technical University of Mombasa. DOI: 10.7176/CER

[17] Almaleeh, M.A., Shitote, S.M., \& Nyomboi, T. (2017). Use of Waste Rubber Tyres as Aggregate in Concrete. Journal of Civil Engineering and Construction Technology. 8 (2), pp 11-19. DOI: 10.5897/JCECT2016.0421

[18] Mang'uriu, G.N., Karugu, C.K., Oyawa, W.O., Aboudha, S.O., \& Mulu, P.U. (2013). Partial Replacement of Natural River Sand with Crushed Sand in Concrete Production [Electronic Version]. Global Engineering and Technologist Review. http://www.jkuat.ac.ke/departments/civil/wp-content/uploads/2013/10/1.-PARTIALREPLACEMENT-OF-NATURAL-RIVER-SAND-WITH-CRUSHED-ROCK-SAND-Getviewmanguriuoyawa.pdf

[19] Mang'uriu, G.N., Mutuku, R.N., Oyawa, W.O. \& Aboudha, S.O. (2012). Properties of Pumice 
Light Weight Aggregate. Civil and Environmental Research. 2 (10), https://iiste.org/Journals/index.php/CER/article/view/3540/3588

[20] Mutabaruka, J.D. \& Pranesh, M.R. (2016). Assessing Suitability of Volcanic Rock of Rwanda as an Aggregate Based on the Engineering Characteristics. International Journal of Civil Engineering and Technology. 7 (6), 449-459

[21] Koech (2017). Full Replacement of Fine Aggregate in Concrete with Crushed Ceramic Waste. Global Journal of Environmental Science and Technology. 5 (6), 488-520.

[22] Mbereyaho, L., Amini, F., Bigirimana, F. \& Isengwe R.C. (2019). The Use of Ceramic Tiles Waste in Concrete as Partial Replacement of Fine Aggregate. Mediterranean Journal of Basic and Applied Sciences. 3 (3). pp 122-130. http://mjbas.com/data/uploads/700011.pdf

[23] Abebaw, \& Muhammed (2020). Effect of Sewage Sludge as Partial Replacement of Fire Aggregate in Concrete at Elevated Temperature: Compressive and Mass Loss Characteristic. Global Scientific Journal. 8 (4), pp 46-57. http://www.globalscientificjournal.com

[24] Makunza, J.K. (2014). Investigation of Fired Animal Bones as Aggregate Replacement in Concrete. RILEM International Workshop on Performance-Based Specification and Control of Concrete Durability, 11-13 June, 2014, Zagreb, Croatia.

[25] Azunnna S.U.(2019). Compressive Strength of Concrete with Palm Kernel Shell as Partial Replacement of Coarse Aggregate. SN Appl. Sci.1, 342. https://doi.org/10.1007/s42452-019$\underline{0334-6}$

[26] Okoroigwe E.C., Saffron C.M. \& Kamdem P.D. (2014). Characterization of Palm Kernel Shell of Materials Reinforcement and Water Treatment. Journal of Chemical Engineering \& Material Science. 5(1). pp 1-6. DOI: 10.5897/JCEMS 2014.0172

[27] Maina, K., Gwaya, A.O., \& Koteng, D.O. (2018). Effects of Different Fine Aggregate on Concrete Strength. Proceedings of the sustainable research and innovation conference. 2-4 May 2018 (135-140). JKUAT Main Campus, Kenya.

[28] Tejiona, T.F.R. (2018). Structural Performance of Sisal Fibers Reinforced Lightweight Concrete with Waste Plastic Pre-coat Volcanic Scoria Aggregates. Msc. Thesis Jomo Kenyatta University of Agriculture and Technology-JKUAT, JKUAT Digital Repository.

[29] Odera, B.J. (2016). Physical and Mechanical Properties of Normal Concrete with Recycled Clay Products and the Plastic Fibres as Coarse Aggregates. Msc. Thesis Jomo Kenyatta University of Agriculture and Technology-JKUAT, JKUAT Digital Repository.

[30] Musembi T.M. Laterized Quarry Dust and Recycled Concrete as Alternative Building Materials. Msc. Thesis-2009 Jomo Kenyatta University of Agriculture and TechnologyJKUAT, JKUAT Digital Repository. http://ir.jkuat.ac.ke/handle/123456789/1278/recentsubmissions?offset $=200$

[31] Almaleeh A.M. Performance of Selected Waste Materials as Aggregates in Concrete. Msc. Thesis-2016 Jomo Kenyatta University of Agriculture and Technology-JKUAT, JKUAT Digital Repository. http://ir.jkuat.ac.ke/bitstream/handle/123456789/4007/M.Sc.\%20THESIS.pdf?sequence=1\&isA llowed $=\mathrm{y}$ 